\title{
Bamboxê Obitikô e a expansão do culto aos orixás (século XIX): uma rede religiosa a froatlântica
}

\author{
Lisa Earl Castillo[1]
}

\begin{abstract}
Resumo
Lembrado em tradições orais na Bahia, em Pernambuco, no Rio de Janeiro e em Lagos (África Ocidental), o nagô liberto Rodolfo Manoel Martins de Andrade (Bamboxê Obitikô) é um dos personagens históricos mais conhecidos do candomblé. Entretecendo tradição oral e pesquisa documental, o presente texto reconstrói sua trajetória de vida, desde a escravidão nos últimos anos do tráfico atlântico, sua alforria e a relação com Marcelina da Silva, ialorixá do terreiro Ilê Axé Iyá Nassô Oká. A segunda parte do texto examina suas viagens, tanto a Lagos quanto a outras partes do império, com ênfase em seu tempo na corte, onde se tornou um líder religioso conhecido entre a população africana de nação mina. O texto também analisa seus vínculos com um conhecido morador negro do Rio de Janeiro, o alferes Candido da Fonseca Galvão, popularmente conhecido como dom Obá II, cujo pai era compadre de Marcelina da Silva.
\end{abstract}

Palavras-chave: africanos libertos; religiões afroatlânticas; Atlântico Negro.

Bamboxê Obitikô and the nineteenth-century expansion of orixá worship in Brazil: case study of an afroatlantic network

\begin{abstract}
Nagô freedman Rodolfo Manoel Martins de Andrade (Bamboxê Obitikô), remembered in oral traditions in Bahia, Pernambuco, Rio de Janeiro and Lagos, was one of candomblés most renowned historical figures. Weaving oral tradition and archival research, the paper traces his path in Brazil. The first part of the paper examines his enslavement in the twilight of the Atlantic slave trade and his relationship to Marcelina da Silva, ialorixá of the terreiro Ilê Axé Iyá Nassô Oká. Next, the paper addresses his travels to Lagos and different parts of Brazil, placing special emphasis on his time in Rio de Janeiro, where he gained a substantial following as a religious leader among the city's West African (Mina) population. The paper also discusses his link to the alferes (ensign) Candido da Fonseca Galvão, popularly known as dom Obá II, whose father was compadre of Marcelina da Silva.
\end{abstract}

Keywords: African freedmen; Afro-Atlantic religions; Black Atlantic.

\section{Bamboxê Obitikô et l'expansion du culte aux orixás au Brésil (XIXesiècle): un réseau religieuxafro-atlantique}

\section{Résumé}

L'affranchi nagô Rodolfo Manoel Martins de Andrade (Bamboxê Obitikô), bien connu dans les traditions orales à Bahia, Pernambuco, Rio de Janeiro et Lagos, était une des personnes historiques plus renommés du candomblé. Larticle actuel utilise la tradition orale et la recherche d'archives comme la base pour une reconstruction historique de sa vie, en train de retracer son chemin de l'esclavage dans les dernières années de la traite négrière transatlantique, sa relation avec Marcelina da Silva, prêtresse du temple Ilê Axé Iyá Nassô Oká, et ses voyages à Lagos et à différentes régions du Brésil, surtout à Rio de Janeiro, où il est devenu un leader religieux entre les africains de nation mina. L'article aborde aussi sa relation avec l'alferes Candido da Fonseca Galvão, populairement connu comme dom Obá II, via son père, qui a été lié aussi a Marcelina da Silva.

Mots-clés: affranchis africains au Brésil ; religions afro-Atlantiques ; Atlantique Noir.

\section{Bamboxê Obitikô y la expansión del culto a los orichás en el Brasil (siglo XIX): una red religiosa afro-atlântica}

\section{Resumen}

Nagô liberto Rodolfo Manoel Martins de Andrade (Bamboxê Obitikô), recordado en las tradiciones orales en Bahia, Pernambuco, Río de Janeiro y Lagos, fue uno de los históricos más reconocidos personajes del candomblé. El presente artículo, tejiendo tradiciones orales y investigación de archivo, reconstruye el camino de su vida, desde la esclavitud en Bahía en los años finales de la trata de esclavos en el Atlántico y su relación con Marcelina da Silva, ialorichá de Ilê Axé Iyá Nasso Oka. El texto también presta atención a sus viajes al Lagos y a diferentes partes de Brasil, con énfasis en su tiempo en Río de Janeiro, donde ganó muchos seguidores entre a población africana de nación mina. El artículo también analisa su relación con el alferes Candido da Fonseca Galvão, popularmente conocido como dom Obá II, cuyo padre fue vinculado Marcelina también.

Palabras clave: libertos africanos; las religiones afro-Atlántico; Negro Atlántico. 
$\mathrm{R}$ odolfo Manoel Martins de Andrade é um dos personagens mais destacados da história do candomblé. Babalaô e sacerdote de Xangô, ele é mais lembrado por seu nome iorubá, Bamboxê Obitikô, e é considerado um ancestral de um dos terreiros mais antigos da Bahia, o Ilê Axé Iyá Nassô Oká, hoje popularmente conhecido como Casa Branca. ${ }^{2}$ Também aparece nas tradições orais de terreiros no Recife e no Rio de Janeiro. Nascido no reino iorubá de Oyó, provavelmente por volta de 1820, foi escravizado já em idade adulta e enviado para a Bahia, mas em poucos anos obteve sua liberdade. Posteriormente, viajou para diversas províncias do então Império do Brasil, ainda retornando à África. Radicou-se em Lagos, mas voltava sempre ao Brasil. Hoje, tem descendentes nos dois lados do Atlântico.

Vale notar que o método divinatório de 16 búzios usado hoje em todo o Brasil, o erindilogun, ou "jogo de búzios", é frequentemente conhecido, entre os adeptos do candomblé, como o "sistema Bamboxê" (Beniste, 1999, p. 13; Braga, 2011), enquanto na literatura etnográfica o papel de Bamboxê Obitikô no período de formação das religiões afro-brasileiras tem sido frequentemente comentado. Em trabalho recente, apresentei as primeiras informações históricas sobre sua vida, apontando para sua atuação em uma rede de libertos que se estendia da Bahia até Pernambuco, Rio de Janeiro e Lagos (Castillo, 2012). O presente trabalho traz novos dados etnográficos e documentais que contribuem com nuanças importantes para a reconstrução histórica de sua história de vida singular, contextualizando sua escravização no quadro político da queda do império de Oyó e do fim do tráfico atlântico de escravos. O texto também analisa suas atividades religiosas no Rio de Janeiro, onde, nas duas últimas décadas do século XIX, Bamboxê Obitikô atraiu uma comunidade de filhos de santo e clientes. Seu status como líder religioso nessa cidade — onde os falantes de línguas bantus eram muito mais numerosos do que os falantes de iorubá - demonstra a importância da Bahia na disseminação do culto aos orixás em outras partes do Brasil. Finalmente, este trabalho aponta para vínculos indiretos entre Bamboxê e um dos mais conhecidos personagens negros do Rio, o alferes Candido de Fonseca Galvão, cujo pai, o liberto nagô Bemvindo da Fonseca Galvão, tinha laços com o Ilê Axé Iyá Nassô Oká por intermédio da ialorixá Marcelina da Silva (Obá Tossi).

\section{Do cativeiro à liberdade}

Não há consenso nas tradições orais sobre as circunstâncias da vinda de Bamboxê à Bahia. Algumas dizem que ele veio como livre, enquanto outras afirmam que era escravizado. A documentação confirma esta última versão. Seu senhor, Manoel Martins de Andrade, era um imigrante português que dividia seu tempo entre Salvador e uma propriedade rural, a fazenda Mutá, no município de Jaguaripe, recôncavo da Baía de Todos os Santos. Andrade se aventurava

2Em iorubá, bamgbose significa "aquele que carrega o ose", o machado de duas lâminas, uma das ferramentas rituais de Xangô (Lima, 1987, p. 71). 
no tráfico interno de escravos, mas ele próprio tinha um número relativamente pequeno de cativos. Quando morreu, em 1871, tinha apenas cinco escravos adultos. Nos anos anteriores, uns 15 outros tinham vivenciado o cativeiro sob seu domínio, sendo posteriormente vendidos a terceiros ou alforriados. Um desses foi Rodolfo Nagô, batizado o final de 1850, quando a participação brasileira no comércio atlântico de escravos estava chegando ao seu fim. ${ }^{3}$

Embora o desembarque de cativos africanos fosse proibido em 1831, na prática a lei teve pouco efeito. Apenas à província da Bahia chegaram mais de 60 mil africanos escravizados ao longo da década de 1840-1850. ${ }^{4}$ Diferentemente da região sudoeste do Brasil, onde as redes comerciais do tráfico se organizavam em torno dos portos da África centro-oeste, os mercadores negreiros na Bahia tinham negócios significativos no litoral do golfo do Benim, em cidades como Uidá e Lagos. Durante o tráfico ilegal, a maioria dos cativos que chegava à Bahia era nagô (falantes de iorubá), aprisionada por guerras regionais relacionadas com a queda do império de Oyó. Até 1850, essa nação formava três quartos da população africana de Salvador, e seu idioma se tornou uma língua franca na cidade, usada por várias etnias (Reis e Mamigonian, 2004, p. 80). Quando Bamboxê atravessou o Atlântico no porão do navio negreiro, é bem provável que muitos dos outros cativos fossem nagôs como ele.

Bamboxê foi batizado em 26 de dezembro de 1850 na freguesia rural de Pirajuia, pertencente a Jaguaripe. O ritual aconteceu em um oratório particular, na casa do sogro de seu senhor. ${ }^{5}$ Segundo as regras brasileiras, os africanos tinham de ser batizados em até um ano após sua chegada, o que indica que Bamboxê deve ter desembarcado na Bahia por volta de 1849. O registro de seu batismo não oferece muitos detalhes, descrevendo-o apenas como "Rodolfo Nagô, adulto", mas outros documentos sugerem que a essa altura ele tivesse 20 e poucos anos de idade. ${ }^{6}$ Junto com ele, dois outros nagôs, escravos do sogro, também receberam o sacramento. Pirajuia tinha poucos habitantes, e os escravos formavam uma minoria da população. Naquele ano, por exemplo, de um total de 143 batismos realizados na freguesia, apenas 21 (15\%) eram escravos, sendo a maioria desses pardos. Apenas oito eram africanos: seis nagôs e dois tapas (nupes). ${ }^{7}$ A fazenda Mutá ocupava a ponta de uma península, e, quando a maré enchia, o acesso era apenas por embarcação. Lá, Bamboxê provavelmente vivia com poucas oportunidades para contatos com outros nagôs, a não ser outros cativos de seu senhor.

${ }^{3}$ Arquivo da Cúria Metropolitana de Salvador (ACMS). Freguesia do Pilar. Batismos 1852-1884, fls. 15v, 16; Freguesia de Pirajuia. Batismos 1832-1854, fl. 327v.; Arquivo Público da Bahia (APB). Inventário de Manoel Martins de Andrade, 03/1292/1761/07; Livro de notas 347, fl.11, Livro de notas 357, fl. 60, e Livro de notas 232. fl. 13; Polícia, maço 6360, Pedidos de passaportes 1864; Arquivo Municipal de Salvador (AMS). Escrituras de compra e venda de escravos: Sé, v. 6 (1852-1854), fl. 58v, e v. 10 (1859-1863), fl. 29; Conceição da Praia, v. 6 (18531855), fl. 33

${ }^{4}$ Banco de dados Slave Voyages. Disponível em: <www.slavevoyages.org>. Acesso em: 4 fev. 2015.

${ }^{5}$ ACMS. Pirajuia. Batismos 1832-1854, fl. 327v.; APB, Inventário de Manoel Martins de Andrade, 3/1292/1761/7. fls. 99-99v.

${ }^{6}$ Em um registro de passaporte de 1873, consta que ele tinha então 55 anos de idade: APB. Polícia. Registros de Passaportes 1873-1874, fl. 34.

${ }^{7}$ ACMS. Pirajuia. Batismos 1832-1854. 
A documentação indica que Manoel Martins de Andrade era um senhor intransigente, que não hesitava em recorrer à violência quando um de seus escravos resistia a uma ordem. Em setembro de 1852, Andrade solicitou permissão da polícia para punir um escravo, Luís Nagô. Segundo o senhor, Luís era desobediente e devia receber 400 chibatadas. Mas o chefe de polícia considerou a severidade exagerada e autorizou "apenas" 150 açoites. Alguns anos depois, "Rodolfo Nagô comprou sua alforria por 1:750\$000 réis. A transação aconteceu em Salvador, em 22 de maio de 1857, seis anos e meio depois de seu batismo. O curto período de sua escravidão certamente influenciou o valor pago, que foi acima da média paga para homens de sua idade. Um dia depois, a nagô liberta Marcelina da Silva, ialorixá do terreiro Ilê Axé Iyá Nassô Oká, vendeu outro africano ao senhor de Bamboxê pela metade do valor que Bamboxê havia pago por sua alforria. ${ }^{8}$ Embora a escritura da venda não faça qualquer menção à alforria de Rodolfo Nagô, o curto espaço de tempo entre as duas transações sugere que houvesse uma espécie de acordo para compensar Andrade pela perda dos serviços de Bamboxê (Castillo, 2012, p. 80-81).

Todas as tradições orais se referem a uma amizade entre a ialorixá e o babalaô, apontando para o envolvimento deste nas atividades religiosas do Ilê Axé Iyá Nassô Oká. Em uma entrevista dada a Pierre Verger em meados do século XX, Mãe Senhora, tataraneta de Marcelina, afirmou que Bamboxê veio ao Brasil junto com Marcelina com o propósito de prestar serviços no terreiro, quando esta retornou após uma viagem de sete anos à cidade iorubá de Ketu, junto com Iyá Nassô, fundadora do Ilê Axé Iyá Nassô Oká (Verger, 1992, p. 89). ${ }^{9}$ Essa versão da chegada de Bamboxê à Bahia tem sido amplamente difundida entre o povo de santo e também na literatura acadêmica. Em trabalhos anteriores, Luis Nicolau Parés e eu apresentamos provas documentais de que a jornada atlântica das duas ialorixás aconteceu no final de 1837, mas mostramos também que o destino foi Uidá, um porto daomeano localizado a 175 quilômetros a sudoeste de Ketu. Ademais, Iyá Nassô nunca retornou ao Brasil, permanecendo em Uidá, onde ela e seu marido fundaram outro templo, enquanto Marcelina estava de volta à Bahia até maio de 1839 (Castillo e Parés, 2007, p. 8; Parés e Castillo, 2015, p. 14 e 23).

A evidência documental sobre essa sequência de acontecimentos é bastante sólida. Ainda é possível que Bamboxê conhecesse as ialorixás na África, mas no caso provavelmente teria sido em Uidá em vez de em Ketu. Uidá era um dos portos mais importantes do tráfico negreiro, e centenas de milhares de cativos passaram por lá durante sua migração forçada ao Brasil. Nos portos negreiros, de vez em quando os cativos aproveitavam-se de oportunidades para conversar com outros. Foi o caso de Mahommah Gardo Baquaqua, capturado no reino de Borgu, ao norte do Daomé, e levado para o Brasil entre 1840 e 1845. Ao chegar a Uidá, encontrou um de seus conterrâneos, que há anos morava lá como escravo (Eltis, 2004; Lovejoy, 2004; Law e Lovejoy, 2007, p. 147-148).

${ }^{8}$ AMS. Escrituras de compra e venda de escravos, Sé, v. 8, 1856-1858, fl. 102

${ }^{9}$ Maria Bibiana do Espírito Santo, ialorixá do terreiro llê Axé Opô Afonjá de Salvador, entre 1943 e 1967. 
Isso sugere que, se Bamboxê chegou a Uidá como cativo, lá pudesse ter conhecido outros falantes de iorubá na cidade, como Iyá Nassô. No entanto, somente teria conhecido Marcelina se chegasse antes do retorno desta à Bahia, em 1839. Por outro lado, é igualmente possível que Bamboxê fosse embarcado em outro porto da região, como Lagos, Badagry ou Porto Novo.

\section{Apenas à província da Bahia chegaram mais \\ de 60 mil africanos escravizados ao longo da década de 1840-1850}

De acordo com a família Bamgbose-Martins de Lagos, que descende de Bamboxê Obitikô, ele pertencia a uma linhagem real de Oyó, e como tal era descendente direto de Xangô. Um dos primeiros alafins (reis) do reino, Xangô foi deificado após sua morte e se tornou um dos mais importantes orixás de Oyó, e seu culto difundiu-se junto com a expansão política do Estado. Conforme mencionado anteriormente, Bamboxê era sacerdote de Xangô. No Brasil, as tradições orais afirmam ainda que foi consagrado a Ogodo, uma "qualidade" desse orixá. ${ }^{10}$ Frequentemente, nomes e práticas associados a determinada qualidade de orixá vêm de mitos e ritos de regiões específicas da iorubalândia. No Brasil, como em Cuba, Xangô Ogodo é especificamente associado aos nupes, grupo étnico cujas terras faziam fronteira a leste e ao norte com o antigo reino de Oyó. Diz-se que a mãe de Xangô era nupe. Além disso, existia uma importante cidade chamada Ogodo. Localizada na margem sul do rio Níger, não muito longe da cidade de Oyó-Ile, Ogodo era originalmente nupe, mas caiu sob o domínio de Oyó no final do século XVIII. Até os anos 1830, a maioria dos grandes comerciantes de Oyó tinha representantes em Ogodo (Law, 1977, p. 158-169 e 211-212; Johnson, 1966, p. 149-150; Verger, 2003 [1981], p. 140; Cabrera, 2007 [1970]). ${ }^{11}$

Uma grande potência regional, o reino de Oyó tornou-se um império que incluía outros Estados iorubás e recebia tributos de reinos vizinhos de outras etnias. O império de Oyó atingiu seu apogeu na segunda metade do século XVIII, sob o alafin Abiodun. Mas, depois de sua morte, por volta de 1789, disputas internas pelo poder começaram a rachar o império. O século XIX trouxe perdas significativas de território, primeiro por rebeliões nas províncias e posteriormente pelas invasões do califado de Sokoto, um ascendente poder rival regional. Entre 1835 e 1837, Ogodo se aliou a Ilorin, uma cidade iorubá controlada por Sokoto desde os anos 1820. Juntas, Ogodo e Ilorin atacaram a capital

${ }^{10}$ Entrevistas com Irene Sowzer Santos (2008-2009), Air José Souza de Jesus (10/6/2010) e Erelu Lola Ayorinde (5/11/2015).

"Na Nigéria hoje, há um Festival de Ogodo na cidade de Oshogbo. Durante o ritual, uma cabaça que contém as pedras do assentamento de Xangô é colocada em cima de um odô (pilão) para receber sacrifícios. Willys Santos, comunicação pessoal, 16 nov. 2015. 
imperial. Oyó-Ile foi incendiada e seus habitantes fugiram para sudeste (Law, 1977, p. 53-54, 211-212 e 295-296; Reis, 2003, p.158-175; Johnson, 1966, p. 186-218).

Seja onde for que Bamboxê vivia - em Oyó-Ile, Ogodo ou em outra cidade -, ele certamente foi deslocado pela turbulência que varreu o império nos anos 1830. Como vimos, a chegada de Marcelina da Silva a Uidá foi em 1837, justamente no período da queda final de Oyó-Ile, uns 500 quilômetros ao nordeste de Uidá. Se Bamboxê a conhecesse lá ou se fosse posteriormente, na Bahia, o certo é que, até 1857, quando Marcelina o auxiliou nas negociações por sua liberdade, os dois já tinham formado laços de amizade. Marcelina também era sacerdotisa de Xangô, e nos anos desde sua volta de Uidá tinha alcançado uma condição de vida confortável, como senhora de escravos e proprietária de imóveis. É possível que ela o ajudasse a se estabelecer financeiramente. Fosse com o auxílio dela ou de outrem, o fato é que apenas um ano depois de sua alforria Bamboxê se tornou senhor de um escravo. Na escritura da compra e em todos os documentos oficiais daí por adiante, ele se identificava utilizando seu nome de batismo acrescentado pelo nome todo de seu ex-senhor: Rodolfo Manoel Martins de Andrade. Em 1866, ele já se tornara proprietário de uma casa de taipa localizada na área rural da freguesia de Santo Antônio Além do Carmo. Bamboxê registrou a propriedade em nome de uma filha menor, Júlia. Para os africanos libertos na Bahia, registrar propriedades em nome de filhos nascidos no Brasil era, desde 1835, uma forma de contornar uma lei provincial, que proibia africanos de adquirir imóveis. Embora a lei não fosse aplicada com rigor, muitos africanos como Bamboxê preferiam ser precavidos. Marcelina da Silva, por exemplo, que tinha três casas a essa altura, havia registrado todas em nome de sua filha crioula, Maria Magdalena (Castillo e Parés, 2007, p. 124-135; Castillo, 2011b, p. 224-234; Reis, 2008 e 2013).

Nos anos 1850, Marcelina já havia desenvolvido uma extensa rede sociorreligiosa, utilizando de forma habilidosa o parentesco ritual do catolicismo. Em junho de 1856, por exemplo, foi madrinha de duas crianças crioulas, cuja mãe africana, Raquel, era escrava de d. José Balthazar da Silveira, um oficial militar branco. O padrinho das crianças, Bemvindo da Fonseca Galvão, também era nagô e liberto. ${ }^{12}$ Esses laços de parentesco ritual provavelmente sinalizaram a inclusão dos novos afilhados e da mãe deles na família de santo do terreiro liderado por Marcelina (Castillo, 2012, p. 71; Parés e Castillo, 2015, p. 18). O padrinho, Bemvindo, já fazia parte da rede sociorreligiosa de Marcelina desde pelo menos 1845, quando se tornara padrinho de um dos escravos da ialorixá. ${ }^{13}$

Ao todo, Marcelina teve pelo menos nove afilhados. ${ }^{14}$ Foi um número relativamente modesto comparado a homens com status social semelhante. Antes

\footnotetext{
${ }^{12}$ ACMS. Santana. Batismos 1846-1865, fls. 246-246v.

${ }^{13}$ ACMS. Sé. Batismos 1829-1861, fl. 227. Evidentemente, Marcelina se tornou integrante da rede estendida do senhor dessas crianças: uma década depois, ele e sua esposa - que era filha do barão do Rio Vermelho foram padrinhos de uma das netas de Marcelina (Castillo e Parés, 2007, p. 145).

${ }^{14}$ Eram três africanas e seis crioulos (três meninos e três meninas). Cf. ACMS. Livros de batismo, freguesias da Conceição da Praia, 1834-1844, fl. 15 (Sofia) e idem, 1844-1889, fl. 50 (Joanna); Sé, 1829-1861, fl. 214v. (Anna e Josefa) e fl. 229v. (Vicência), idem, 1861-1877, fl. 18v. (Braz); Santa Anna 1846-1865, fls. 246-246v. (Dário e Túlia) e 1865-1878, fl. 228v. (Agostinho).
} 
de 1850, com a constante chegada de novos cativos da África, libertos muito bem-sucedidos agregavam dezenas de afilhados. Entretanto, os homens se destacavam mais no apadrinhamento, sobretudo de escravos, em razão da prática de invocar Nossa Senhora como madrinha simbólica. Quase sempre, quem "tocava a coroa de Nossa Senhora" era um homem, que efetivamente se tornava um segundo padrinho. Por isso, mulheres libertas tendiam a ter poucos afilhados comparado com seus pares do sexo masculino (Mattoso, 1992, p. 175; Parés e Castillo, 2015, p. 16-18). Por exemplo, o compadre de Marcelina, Bemvindo da Fonseca Galvão, que obteve sua liberdade em 1836, no mesmo ano em que ela foi alforriada, tinha 21 afilhados. ${ }^{15}$

Tanto no caso de Marcelina quanto no de Bemvindo, a maioria de seus afilhados foi batizada antes do fim do tráfico atlântico. Não foi mera coincidência. Depois de 1850, sem a chegada constante de africanos ao Brasil, o número de batismos caiu bastante. Bamboxê entrou no catolicismo no mesmo ano em que o tráfico atlântico encerrou e por isso tinha oportunidades reduzidas para utilizar o apadrinhamento como ferramenta de ascensão social. Embora os crioulos, sobretudo os de pais africanos, fossem outro grupo demográfico disputado pelos africanos libertos em busca de afilhados, na escolha de padrinhos, pesava o prestígio do candidato, medido em grande parte pelo tamanho da sua rede social. Ao que parece, Bamboxê passou seus primeiros anos no Brasil na propriedade rural de seu senhor, onde tinha poucos outros africanos, como vimos. Mesmo depois de sua alforria, quando já morava na capital, seu padrão de vida era bem abaixo do nível de Marcelina da Silva ou de Bemvindo da Fonseca Galvão. Além do escravo e da humilde casa já descritos, os bens de Bamboxê se limitavam a apenas outro cativo, adquirido em 1864 e vendido dois anos depois (Castillo, 2012, p. 82-83). Diante da expectativa social de que o padrinho tivesse a capacidade de ajudar seus afilhados materialmente, era um patrimônio relativamente parco. Em compensação, Bamboxê Obitikô certamente gozava de outro tipo de prestígio, como sacerdote de Xangô e babalaô.

Há evidência de dois afilhados, ambos batizados em Salvador. Em 1858, na freguesia do Passo, "Rodolfo Manoel de Andrade" batizou uma criança crioula, cuja mãe, africana, era escrava de um africano liberto. ${ }^{16}$ Dez anos mais tarde, na freguesia de São Pedro, "Rodolfo Manoel Martins" batizou o escravo Zacharias cabra, recém-nascido. Não houve madrinha, mas outro africano liberto, Joaquim Vieira da Silva, serviu como intermediário de Nossa Senhora. ${ }^{17}$ Joaquim é outra figura importante nas tradições orais, lembrado mais por seu nome iorubá, Obá Sanyá. Como Bamboxê, era devoto de Xangô e também considerado ancestral do Ilê Axé Iyá Nassô Oká. De acordo com a memória oral, Bamboxê Obitikô e Obá Sanyá eram amigos próximos. Com a escolha desses

\footnotetext{
${ }_{15}$ ACMS. Sé. Batismos 1829-1861, fls. 195, 196, 198v, 225v, 227, 231, 257v, 278v, 281v, 303, 315; Santana. Batismos 1830-1848, fl. 238; Santana. Batismos 1846-1865, fl. 125; Conceição da Praia. Batismos 1844-1864, fl. 14v.; Passo. Batismos 1817-1879, fl. 196v:; APB. Livro de notas 257, fl. 131v. Estou grata a Urano Andrade por compartilhar este último documento.

${ }^{16}$ ACMS. Passo. Batismos 1817-1859, fl. 248v.

${ }_{17}$ ACMS. S. Pedro. Batismos 1865-1903, fl. 29v
} 
compadres, não resta dúvida de que os pais de Zacharias queriam que ele fosse iniciado no culto de Xangô, provavelmente por seus próprios padrinhos, como no caso de outra criança nascida no ano seguinte, a crioula Eugênia Anna dos Santos. Filha de santo de Bamboxê Obitikô, de Obá Sanyá e da ialorixá do Ilê Axé Iyá Nassô Oká, "Aninha”, como era conhecida, foi iniciada para duas qualidades de Xangô, Ogodo e Afonjá. Como adulta, tornou-se fundadora de um dos terreiros mais conhecidos de Salvador, o Ilê Axé Opô Afonjá (Castillo, 2012, p. 83-89; Verger, 2003 [1981], p. 28-29; Lima, 1987, p. 53-65).

\section{Uma rede atlântica}

Não se sabe se Rodolfo Manoel Martins de Andrade e Joaquim Vieira da Silva se conheceram no batismo de 1868 ou se antes, mas o certo é que, até 1872, já tinham uma amizade, pois naquele ano viajaram juntos para Recife, chegando em 22 de março e lá permanecendo por oito meses. No cativeiro, Joaquim havia sido marinheiro. Seu senhor era um comerciante negreiro que tinha negócios no golfo do Benim, mas, quando morreu, em 1866, Joaquim foi coartado. A viagem ao Recife foi a primeira que Joaquim fizera fora da Bahia após sua liberdade. Para Bamboxê, foi a primeira de muitas outras viagens, tanto dentro do Império do Brasil quanto também para a África (Castillo, 2012, p. 82-89). ${ }^{18}$

A população africana do Recife era grande, a terceira maior das capitais brasileiras. Em 1872, havia cerca de 950 africanos libertos na cidade, número um pouco maior do que o de africanos escravizados. Embora não haja dados confiáveis sobre as etnias, muitos como Bamboxê eram falantes de iorubá que haviam chegado ao Brasil entre 1831 e 1850, durante o período do tráfico ilegal (Costa, 2013, p. 37-48). Não se sabe o motivo da viagem de Bamboxé e Obá Sanyá ao Recife. Uma vez que Joaquim era marinheiro, é possível que ele tenha conhecido Recife durante uma de suas muitas viagens. Também é possível que ele ou Bamboxê tivesse parentes por lá. Como já foi mencionado, era grande o número de nagôs enviados para a escravidão atlântica. Não era raro, portanto, que pessoas da mesma cidade fossem capturadas e embarcadas juntas para 0 Brasil, sendo separadas apenas depois de vendidas (Oliveira, 1996).

Em todo caso, é provável que as atividades religiosas de Bamboxê e Obá Sanyá influenciaram sua decisão de visitar a cidade. De fato, no terreiro mais antigo de Recife, o sítio de Pai Adão, Obá Sanyá é considerado um ancestral, e há evidências também da participação de Bamboxê..$^{19}$ Diz-se que o templo foi fundado em meados de 1870 por uma liberta egbá, Ignez Joaquina da Costa (Ifá Tinuke). ${ }^{20}$ Parece provável que durante sua estada em Recife, em 1872, Obá Sanyá e Bamboxê Obitikô estivessem envolvidos, de alguma forma, na fundação desse terreiro (Campos, 2005, p. 9-34).

\footnotetext{
18 Jornal do Recife, p. 1, Passageiros, 23 mar. 1872.

19 Sou grata à historiadora Valéria Gomes Costa por essa informação. Xangô tinha uma importância especial em Recife, tanto que "xangô" lá se tornou um termo genérico para o culto aos orixás.

20 Os egbá são um subgrupo iorubá, muito explorado pelo tráfico de escravos entre 1820 e 1850.
} 
Em Recife, outro liberto egbá, Eduardo Américo de Souza Gomes (Fasesi), foi ao encontro de Bamboxê e de Obá Sanyá. Eduardo tinha morado na Bahia durante o cativeiro, mas havia passado os últimos quatro anos em Lagos. Voltou à Bahia em 1872, seguindo imediatamente para Pernambuco e retornando para a Bahia poucas semanas depois já acompanhado de três menores crioulos que pretendia levar para a África. Muito provavelmente, sua guarda dessas crianças havia sido intermediada por Bamboxê e Joaquim (Castillo, 2012, p. 90-92). ${ }^{21}$ Algumas semanas depois, Bamboxê e Joaquim também voltaram a Salvador, embarcando em 2 de outubro de 1872 a bordo do vapor Cruzeiro do Sul. De acordo com a lista de passageiros, "Rodolfo M. M. de Andrade" estava em companhia de dois menores, descritos como seus filhos. ${ }^{22}$

\section{Marcelina também era sacerdotisa de Xangô, e nos anos desde sua volta de Uidá tinha alcançado uma condição de vida confortável, como senhora de escravos e proprietária de imóveis}

No final de novembro do mesmo ano, Eduardo partiu para Lagos, levando os jovens que vieram com ele de Pernambuco e duas garotas, ambas da Bahia. Uma, Querina, tinha 12 anos de idade e havia sido escrava de Marcelina da Silva. A outra menina, Sophia, de 15 anos de idade, era filha de Esperança Rita Pereira, uma afriana liberta. ${ }^{23}$ Não fica claro se a mãe de Sophia tinha vínculos com o Ilê Axé Iyá Nassô Oká, mas parece provável, uma vez que Marcelina tinha dois sobrados de aluguel na pequena freguesia da rua do Passo, onde Sophia e sua mãe moravam (Castillo, 2012, p. 91).

Em 10 de junho de 1873, sete meses após a partida de Eduardo, Rodolfo Manoel Martins de Andrade solicitou permissão para viajar para a costa da África. Os registros de passaportes mostram que ele viajava com cinco crianças crioulas. Três delas, Júlia, Lucrécia e Theóphilo, eram seus próprios filhos. Os outros dois, Cosme e Rosalina, eram de Pernambuco, certamente os mesmos que haviam vindo com ele de Recife. Uma jovem mina liberta, Feliciana Maria da Conceição, que viera de Recife no mesmo vapor que Bamboxê, recebeu um passaporte no mesmo dia. Dois meses depois, em 7 de agosto de 1873, o grupo inteiro partiu para Lagos. ${ }^{24}$

\footnotetext{
${ }^{21}$ Jornal do Recife, p. 3, 11 set. 1872

22 Jornal do Recife, p. 1, 4 out. 1872

${ }^{23}$ APB. Polícia. Correspondência sobre passaportes, 1847-1872, maço 6354.

${ }^{24}$ A informação dada pelo Jornal do Recife de que os menores que vieram de lá com Bamboxê fossem seus filhos (cf. nota 22) foi um equívoco, pois o registro do passaporte tirado na Bahia deixa clara a distinção entre seus próprios filhos e os menores pernambucanos que viajavam com ele.
} 
Sem dúvida, Marcelina da Silva, como ialorixá do terreiro a que esses viajantes pertenciam, dava seu apoio a essas articulações atlânticas. Afinal, ela tinha um histórico semelhante. Em 1839, quando retornara da África, deixou sua filha Maria Magdalena, com 10 anos de idade, sob o poder de Iyá Nassô. Vinte anos depois, já adulta, Maria Magdalena voltou à Bahia ao reencontro da mãe. Parece provável que durante os anos de separação mãe e filha mantiveram contatos periódicos por intermédio de outros africanos que atravessavam o mar entre a Bahia e a costa da Mina, como o fizeram outras famílias agudás. Frequentemente, viajantes africanos serviam de elo entre os dois lados do mar, levando cartas e encomendas para entregar no outro lado. Possivelmente, o próprio Joaquim Vieira da Silva, em suas viagens atlânticas, intermediasse contatos entre Marcelina e sua filha (Parés e Castillo, 2015, p. 23; Castillo, 2012, p. 66; Falheiros, 2013, p. 51-61; Castillo, 2016).

As comunidades lusófonas do golfo do Benin datam do século XVIII. Até meados de 1800, Uidá tinha a maior e mais antiga. Mas, depois de 1851, quando os ingleses tomaram Lagos, essa última cidade começou a atrair um número cada vez maior de libertos retornados do Brasil. Em 1865, Lagos tinha cerca de mil "brasileiros", em uma população total de 25 mil. Alguns haviam adquirido sua liberdade recentemente, enquanto outros haviam ficado no Brasil por décadas, até tomar a decisão de retornar (Law e Mann, 1999; Cunha, 2012, p. 108-127; Castillo, 2016; Castillo, 2012, p. 72-73).

Pouco tempo após seu desembarque em Lagos em 1873, Bamboxê Obitikô adquiriu um terreno no bairro brasileiro, registrando-o em seu nome lusófono, Rodolfo Manoel Martins de Andrade. Conforme assinalado anteriormente, Bamboxê Obitikô era também babalaô, ou seja, adivinho do oráculo de Ifá. A memória de sua habilidade como intermediário entre o mundo dos espíritos (orun) e o dos seres vivos (aye) é relembrada pelo nome do compound estabelecido por ele, Ilê Ajolojo, que significa "casa daquele que dança na chuva e tem poder sobre ela". A casa ainda abriga altares de Xangô e de quatro outros orixás Obatalá, Exu, Ogum e Oxum —, que foram assentados por Bamboxê. De acordo com seus descendentes lagosianos, ele exercia um papel central no culto a Xangô na cidade, o que parece ser confirmado por uma reportagem de jornal de 1895 sobre uma reunião dos chefes da cidade. Entre as pessoas presentes foi certo Bamgbose, descrito como líder dos devotos de Xangô (Castillo, 2011a, p.69). ${ }^{25}$

De acordo com o antropólogo Milton Guran, o catolicismo foi fundamental para a formação da identidade agudá, compreendido como símbolo da experiência coletiva no Brasil (Guran, 2002, p. 50-53). Bamboxê Obitikô não era uma exceção, apesar de seu profundo envolvimento nas práticas religiosas iorubás. No contexto de Lagos, a colonização inglesa favorecia adesão ao protestantismo, mas Bamboxê levava os filhos que teve em Lagos para ser batizados na Igreja Católica. Entretanto, como muitos outros agudás, nunca abraçou o casamento

${ }^{25}$ Entrevistas com Erelu Lola Ayorinde (13/10/2015, 27/10/2015 e 1/11/2015) e Chief Erinfolami, Oloye Otun do Ilê Ajolojo (26/9/2010); Lagos Weekly Record, p. 5, 13 jul. 1895. O termo compound se refere a um conjunto de domicílios pertencentes à mesma família e construídos no mesmo terreno, com novas unidades surgindo ao longo das gerações. 
cristão, estruturando sua família de acordo com a poliginia tradicional iorubá. Teve pelo menos três esposas. A mãe do primeiro filho nascido em Lagos, aparece no registro de batismo como "Firmina" da Conceição, mas decerto se tratava de Feliciana da Conceição, a mina liberta que veio com Bamboxê de Pernambuco. O filho nasceu poucas semanas após a chegada do pai a Lagos, em 1873, então a mãe deve ter engravidado no Brasil. ${ }^{26} \mathrm{~A}$ mãe de outro filho era Rosalina, a garota crioula que havia vindo de Recife junto com Bamboxê. A mãe de três filhos é identificada nos primeiros registros como Orisabukola e depois como Esperança Orisabukola, o que sugere que, quando Bamboxê a tomou como esposa, não tinha sido batizado ainda. Provavelmente, nunca morou no Brasil. No caso dela, fica bastante claro que a decisão de batizar os filhos partiu do pai (Castillo, 2012, p. 102). ${ }^{27}$

Eduardo Américo de Souza Gomes também teve várias esposas em Lagos. Uma, Querina da Silva, era a ex-escrava de Marcelina da Silva que foi a Lagos com ele. Outra era Júlia, a filha mais velha de Bamboxê. Sem dúvida, elas se conheciam desde a infância por meio do Ilê Axé Iyá Nassô Oká. Eduardo e Júlia tiveram dois filhos: Júlio, batizado em 1875, e Felisberto, batizado em 1878 (Castillo, 2012, p. 91-92 e 97-100). ${ }^{28}$ Logo após o batismo de Felisberto, Bamboxê retornou para Salvador, desembarcando em 26 de setembro de 1878, juntamente com o liberto Eliseu do Bomfim, um sacerdote do culto de egúngún (ancestrais) também vinculado ao Ilê Axé Iyá Nassô Oká. ${ }^{29}$ Os registros da alfândega mostram que ambos os homens traziam produtos africanos, entre os quais grandes quantidades de nozes de cola (obi). Para agudás como Bamboxê, que mantinham contatos com o Brasil, a importação de mercadorias ajudava a cobrir os custos de suas viagens, talvez até as motivando (Castillo, 2012; Omidire e Amos, 2012; Cunha, 2012, p. 158-162; Santos, 2013, p. 241-243; Matory, 2005, p. 31, 95-101 e passim).

Essa visita ao Brasil durou um ano. Bamboxê passou a maioria do tempo em Salvador, mas fez uma viagem de dois meses ao Rio de Janeiro, e outra, provavelmente mais curta, para Pernambuco. Em 16 de setembro de 1879, regressou para Lagos. Sua próxima visita ao Brasil começou no início de 1886 e durou até o final de outubro do ano seguinte. Como veremos mais adiante, nessa visita ele passou quase um ano na corte. Evidentemente, fez outra viagem ao Brasil cerca de cinco anos depois, pois esteve novamente no Rio de Janeiro em 1893. Mas, no final do ano seguinte, já estava de volta a Lagos (Castillo, 2012, p. 102103). Levando em conta que cada travessia atlântica demorava no mínimo três

\footnotetext{
${ }^{26}$ Se Feliciana/Firmina da Conceição fosse a mesma mulher identificada em outro registro como "Philomena" da Conceição, ao todo essa esposa teve três filhos com Bamboxê.

${ }^{27}$ O nome Orisabukola significa "o orixá fortalece o prestígio", o que indica que essa esposa estava envolvida nas práticas religiosas tradicionais (Oduyoye, 2001, p. 80).

${ }^{28}$ Entrevista com Irene Sowzer Santos (2006). Fundação Pierre Verger, Notas de Pesquisa/Brésiliens en Afrique: entrevista com Caetana America Sowzer, s.d.

${ }^{29}$ Eliseu era compadre de Marcelina da Silva e o pai do babalaô Martiniano do Bomfim, personagem legendária na memória do candomblé. Para mais sobre essa família, ver, entre outros, Castillo (2012, p. 69-78) e Omidire e Amos (2012).
} 
semanas e podia levar até seis, a depender dos ventos, o itinerário de viagens era puxado. ${ }^{30}$

Os últimos registros que consegui localizar sobre Bamboxê Obitikô são do final de 1897, quando seu nome aparece em listas de destinatários de cartas registradas que haviam chegado aos correios de Lagos, provavelmente vindas do Brasil. Talvez em resposta às cartas, ele ainda fez mais uma viagem ao Brasil, porque faleceu na Bahia nos primeiros anos do século XX. Seus restos mortais estão enterrados na igreja de uma das mais importantes irmandades negras de Salvador, a de Nossa Senhora do Rosário dos Pretos do Pelourinho (Castillo, 2012, p. 101-103). Ao longo da vida, Bamboxê Obitiko passou relativamente pouco tempo em Salvador, provavelmente menos de duas décadas no total. Ainda assim a memória de seu legado é forte, especialmente no que diz respeito aos cultos de Xangô e de Ifá. Seu papel como pai espiritual da ialorixá Eugênia Anna dos Santos é muito conhecido, mas ele também iniciou outras pessoas, incluindo Manoel do Bomfim, que fundou um terreiro a poucos metros do Ilê Axé Iyá Nassô Oká. Outro filho de santo seu, apelidado de Manoel Xangô, liderava um terreiro perto do Matatu, o bairro semirrural onde Bamboxê morou durante seus últimos anos de vida (Castillo, 2008, p. 69 e 124-136; Ramos, 2014, p. 6; Lima, 1987).

Dos três filhos brasileiros de Bamboxê, dois, Theóphilo e Lucrécia, permaneceram em Lagos pelo resto de suas vidas. Mas Júlia, a mais velha, herdou o espírito independente do pai e seu gosto por viagens, atravessando várias vezes o oceano. Em sua primeira volta à Bahia, em setembro de 1886, deixou o marido em Lagos, trazendo apenas o filho Felisberto. Não há informações sobre outro retorno a Lagos, e em 1893 ela esteve no Rio de Janeiro, o que pode sugerir que ficou no Brasil por todos os seis anos. Não se sabe exatamente quando, mas Júlia mais tarde retornou para a África, pois em abril de 1896, quando o navio Alliança aportou na Bahia, vindo de Lagos, entre seus passageiros estava "Maria Júlia Martins". Essa pode ter sido sua última viagem atlântica. Seu filho, Felisberto Sowzer, se estabeleceu definitivamente em Salvador, tornando-se um conhecido mestre de obras e membro da irmandade do Rosário. De acordo com a memória oral, Felisberto era iniciado para Ogum e também era babalaô, enquanto Júlia era ialorixá e consagrada a Xangô. Até 1905, mãe e filho já haviam se estabelecido no bairro do Matatu, onde Bamboxê vivenciou seus últimos anos. Lá ainda moram descendentes de sua bisneta caçula, Irene Sowzer Santos (Castillo, 2008, p. 70-71 e 2012, p. 98-99; Souza, 2011). ${ }^{31}$

\footnotetext{
30 Jornal do Recife, p. 2, 27 jan. 1879; Jornal do Brasil, p. 1, 30 maio 1893.

${ }^{31}$ AMS. Registros de IPTU, Brotas, 1905, v. 2, fl. 33v. O sobrenome Sowzer é uma versão anglófona de Souza, o segundo sobrenome do pai de Felisberto. O outro filho de Maria Júlia, Júlio, permaneceu na Africa, finalmente se mudando para Abeokuta. Theóphilo faleceu em Lagos em 25 de novembro de 1927. Entrevista com Irene Sowzer Santos, 2006. Fundação Pierre Verger, Notas de Pesquisa/Brésiliens en Afrique: entrevista com Caetana America Sowzer.
} 


\section{Rio de Janeiro}

Maria Júlia Martins de Andrade faleceu na Bahia em 18 de fevereiro de 1926. Após sua morte, Felisberto Sowzer publicou notas nos jornais locais informando sobre as missas que seriam celebradas para a alma dela. Embora não fossem mencionados, os rituais fúnebres de axexê foram realizados durante os seis dias antes de cada missa, como ainda é o costume no candomblé. Missas foram rezadas também no Rio de Janeiro, na igreja matriz da freguesia do Santíssimo Sacramento e na igreja da irmandade do Rosário, o que sinaliza a presença de laços afetivos com pessoas naquela cidade. ${ }^{32}$ Vinte anos antes, em 1905, uma matéria publicada na Gazeta de Notícias pelo jornalista João do Rio já aponta para a atuação da família na cidade. Referindo-se a Felisberto pelo apelido de "Benzinho", o jornalista o descreve como "um terrível feiticeiro", cujo avô, "o ilustre Bamboché", era "celebrado entre os africanos como um especialista dos idams [isto é, feitos mágicos]" e foi o fundador de "uma dinastia tão bem relacionada com as potências ocultas". Essas evidências documentais respaldam o que a tradição oral já afirmava sobre a importância de Bamboxê e de seu neto no culto aos orixás no Rio (Conduru, 2010, p. 180-181 e 187). ${ }^{33}$

A demografia da população africana no Rio era muito diferente da de Salvador. Como já vimos, os falantes de iorubá predominavam na Bahia na metade do século XIX. Mas, na corte, a maioria dos africanos era falante de línguas bantus, do atual Angola, Congo e Moçambique. Entretanto, nos anos 1830, o número de africanos da costa da Mina, conhecidos como minas, começou a crescer, estimulado pelo tráfico interno de escravos que deslocava cativos do nordeste para o sudeste e o sul. Ao mesmo tempo, havia uma migração paralela de libertos, muitos deles minas também. Alguns eram comerciantes que iam e voltavam, enquanto outros se radicaram no Rio de Janeiro. Embora os minas no Rio nunca superassem, numericamente, os falantes de bantu, até os anos 1850 uma minora significativa dos africanos que trabalhavam no ganho cerca de $30 \%$ - eram minas. Até meados de 1880, os minas tinham se tornado a maioria esmagadora desse segmento (Florentino, 2002, p. 27-28; Farias, 2012, p. 160-164; Farias, Gomes e Soares, 2006, p. 91-92; Sampaio, 2009b; Graham, 2012; Reis e Mamigonian, 2004, p. 99-105).

Como vários pesquisadores já observaram, esse influxo de africanos de nação mina fornece um pano de fundo para a implantação e o crescimento do culto aos orixás no Rio de Janeiro. O estudo pioneiro de João do Rio deixa claro que, até os primeiros anos do século XX, havia muitos devotos aos orixás na corte, com casas de culto bem estabelecidas. Essas migrações do nordeste também explicam por que muitas tradições orais do Rio se referem à presença de negros "baianos". Um caso paradigmático é de Tia Ciata, uma sacerdotisa de Oxum que teria nascido na Bahia e chegado ao Rio nos anos 1870. Mas outros

\footnotetext{
32 Jornal do Brasil, p. 18, 19 mar. 1926; A Noite, p. 6, 17 maio 1926; O Jornal, p. 13, 18 maio 1926; A Capital, p. 2, 18 fev. 1927.

${ }_{33}$ Gazeta de Notícias, p. 1, 2 mar. 1905; grifo do original. Sou grata a Maria Clementina Pereira Cunha por indicar essa fonte.
} 
"baianos" eram naturais da África e adquiriram essa identidade por ter desembarcado naquela província quando chegaram ao Brasil. Nessa categoria, inserese Bamboxê Obitikô. Conta-se que os primeiros axés de um dos terreiros mais antigos da cidade, o Ilê Axé Opô Afonjá, foram plantados em 1886 no bairro da Saúde, em uma cerimônia que envolveu Bamboxê Obitikô, Obá Sanyá e a filha de santo de Bamboxê mencionada anteriormente, Eugênia Anna dos Santos, mais conhecida como Mãe Aninha (Sampaio, 2009b, p. 73-74; Rio, 2006; Silva, 1999, p. 70 e 81-84; Cunha, 2015; Moura, 1995, p. 98; Rocha, 2000, p. 33; Augras e Santos, 2005). ${ }^{34}$

Os registros de passageiros que embarcaram na Bahia para o Rio de Janeiro em 1886 não dão nenhuma pista sobre Joaquim Vieira da Silva ou Eugênia Anna dos Santos, mas mostram que Bamboxê Obitikô passou quase todo aquele ano na corte. Como já foi mencionado, ele havia chegado à Bahia vindo de Lagos no início do ano. Em 30 de março, Rodolfo Manoel Martins de Andrade deixou Salvador a bordo do vapor Ville de Pernambuco, chegando ao Rio em 2 de abril. Cinco meses depois, na noite de 24 de agosto de 1886, foi preso em uma casa na freguesia do Sacramento, enquanto a polícia investigava uma denúncia sobre um zungu. De origem bantu, o termo zungu se referia a casas de pensão cujos proprietários eram pessoas de cor, onde libertos e escravos se reuniam para encontros sociais e também para rituais. Outra reportagem descreveu o local como uma "casa de dar fortuna". ${ }^{35}$

Localizada na rua da Alfândega, 303, entre Núncio e Regente, a casa ficava em uma área conhecida por zungus e "casas de feitiço" (Farias et al., 2006, p. 83-101; Soares, 2007, p. 217).$^{36}$ Identificado como o proprietário, Rodolfo Manoel Martins de Andrade recebeu uma multa de $30 \$ 000$ réis. Quatro mulheres encontradas com ele, todas de nação mina e "entregues ao jogo da feitiçaria”, também foram presas: Maria da Conceição, Ignez da Conceição, Maria Thereza e Leopoldina Maria da Conceição. ${ }^{37}$ Todas as mulheres tinham cabeças raspadas, um detalhe significativo. ${ }^{38}$ No candomblé, assim como no culto aos orixás na África, a raspagem das cabeças de noviços é um elemento fundamental dos preceitos da iniciação. Obviamente, a polícia tinha se deparado com uma cerimônia de iniciação liderada por Bamboxê. As tradições orais

\footnotetext{
${ }^{34}$ Esse terreiro é distinto de outro de mesmo nome, fundado na Bahia em 1910 por Eugênia Anna dos Santos, mas suas histórias são interligadas. Aninha, que nasceu em 1869, tinha apenas 17 anos em 1886, muito jovem para liderar a fundação de um terreiro. As primeiras evidências concretas de sua presença no Rio de Janeiro são dos anos 1920 (Santos, 2007, p. 267-268). Sobre sua vida, ver Lima (1987).

35 APB. Registros de passaportes 1885-1890, maço 5910; Saídas de passageiros, v. 55, 1886-1890; Gazeta de Notícias, Rio de Janeiro, p. 5, 3 abr. 1886; O Rio de Janeiro, p. 1, 26 ago. 1886; Gazeta de Notícias, Rio de Janeiro, p. 2, 26 ago. 1886.

${ }^{36}$ O Rio de Janeiro, p. 1, 26 ago. 1886; Gazeta de Notícias, Rio de Janeiro, p. 2, 26 ago. 1886. A casa ficava a uma quadra do terreiro do pai de santo José Sebastião "Juca" Rosa, preso em 1870. Na virada do século XX, Tia Ciata morava na rua da Alfândega, 304 - em frente ao local onde Bamboxê foi preso em 1886 (Sampaio, 2009a, p. 15; Rio, 2006, p. 44).

${ }^{37}$ O Rio de Janeiro, p. 1, 26 ago. 1886; Gazeta de Notícias, Rio de Janeiro, p. 2, 26 ago. 1886. A coincidência dos "sobrenomes" dessas mulheres não significa parentesco carnal, nem que fossem escravas do mesmo senhor. Nossa Senhora da Conceição era uma das invocações mais populares da Virgem Maria, e muitas africanas adotaram seu nome para sinalizar sua devoção.

${ }^{38}$ Gazeta de Notícias, Rio de Janeiro, p. 2, 26 ago. 1886.
} 
sobre a fundação do Ilê Axé Opô Afonjá não mencionam a rua da Alfândega, nem os nomes das mulheres lá encontradas com Bamboxê. Isso sugere que a cerimônia interrompida pela polícia em 1886 era outra, e que as atividades de Bamboxê no Rio eram mais extensas, sendo seus seguidores ainda mais numerosos do que se lembra hoje.

\section{O catolicismo foi fundamental para a formação da identidade agudá, compreendido como símbolo da experiência coletiva no Brasil}

Muito provavelmente, a Maria da Conceição presa com ele, era uma quitandeira mina que morava na mesma rua, na casa número 315, e que já tinha sido assunto de notícias de jornais. Em 1883, foram publicadas acusações anônimas contra ela, alegando que sua casa era um zungu e que tinha forçado sua filha, Eva, a ter relações sexuais com um homem rico, com o intuito de lucrar financeiramente. ${ }^{39}$ Quando as mesmas acusações se repetiram, em março de 1886, ela foi à polícia e deu queixa contra o alferes Candido da Fonseca Galvão, alegando que ele havia invadido sua casa com a intenção de estuprar Eva. ${ }^{40}$ Natural da Bahia, Candido era um dos negros mais conhecidos do Rio de Janeiro. Tinha recebido sua patente pelo serviço prestado na Guerra do Paraguai e publicava comentários regularmente em jornais sobre a política nacional e questões relacionadas com os afrodescendentes. Sua carreira como autor tinha começado na capital baiana e continuava após sua mudança para o Rio, por volta de 1879 . Mas sua visibilidade pública se devia mais à sua controversa reivindicação de ser neto de Abiodun, que, como já foi mencionado, foi o rei de Oyó durante o auge do império na segunda metade do século XVIII. Apropriando-se de uma das palavras iorubás para rei, obá, Candido se autointitulava "príncipe dom Obá II", referindo-se a seu pai como “príncipe dom Obá I”. Desde 1885, Candido procurara nomeação como embaixador do Brasil em Lagos, com base nessa descendência. ${ }^{41}$

O historiador Eduardo Silva, cujo livro sobre essa figura extraordinária é ainda a melhor referência sobre o assunto, afirmou, com base nos próprios escritos de Galvão, que ele nasceu e cresceu em Lençóis, na região da Chapada Diamantina, interior da Bahia (Silva, 1997, p. 20, 38, 187 e passim) ${ }^{42}$ Entretanto, outros documentos indicam que Candido era natural de Salvador, sendo batizado na freguesia da Sé em 13 de maio de 1838. Seu pai, o liberto

${ }^{39}$ Corsário, p. 4, 27 fev. 1883.

40 Diário de Notícias, p. 3, 24 mar. 1886; p. 1, 28 jul. 1886; Gazeta de Notícias, Rio de Janeiro, p. 1, 24 mar. 1886; p. 1, 28 jul. 1886; O Carbonário, p. 4, 14 jun. 1886; p. 4, 30 jul. 1886. Tudo indica que Galvão fosse o autor das denúncias anônimas contra Maria da Conceição.

${ }^{41}$ A Nação, Rio de Janeiro, p. 4, Parte ineditorial, 28 mar. 1874. Esse texto identifica os jornais baianos de que Candido era colaborador: Correio da Bahia, Diário da Bahia, Jornal da Bahia e Alabama.

${ }^{42}$ Sobre Candido da Fonseca Galvão, ver também Kraay (2012). 
nagô Bemvindo da Fonseca Galvão — o compadre de Marcelina da Silva, como referido acima - morava lá desde o cativeiro. ${ }^{43}$ É muito provável, portanto, que Bamboxê Obitikô, desde seus primeiros anos de liberdade em Salvador, conhecesse muito bem Bemvindo e sua família por meio da comunidade religiosa do Ilê Axé Iyá Nassô Oká.

Se os laços de compadrio entre Bemvindo da Fonseca Galvão e a ialorixá já indicam algum envolvimento por essa família de libertos em práticas religiosas afro-brasileiras, a evidente familiaridade de Candido com o universo dos orixás não deixa dúvida. Seus escritos eram guarnecidos de referências explícitas aos orixás, demonstrando um conhecimento sofisticado de seus atributos e mitologia. Frequentemente, ele invocava sua proteção, uma postura inédita naqueles tempos. A primeira menção que consegui localizar veio no jornal soteropolitano O Monitor, em 13 de dezembro de 1878. Nessa nota, Candido reclamava da suspensão de sua pensão militar, invocando a proteção do Senhor do Bonfim e do orixá guerreiro Ogum na luta para reestabelecer o benefício. Nos anos 1880, quando já morava no Rio de Janeiro, Candido passou a usar um retrato estilizado de si mesmo para ilustrar suas publicações, rodeado pelos símbolos iconográficos de Xangô, Ogum, Oxum e Oxóssi, inseridos nos pontos cardinais (Silva, 1999, p. 168-173). Em seus escritos, vários orixás começam a ser mencionados, sendo os mais comuns Xangô e Oyá-Iansã. É interessante constatar que, muitas vezes, Candido se referia a Santa Bárbara, mas atribuía-lhe atributos de oyá, como um "escudo africano" - evocando o caráter guerreira de Oyá - e "os raios de Xangô" — aludindo a seu casamento com esse orixá. Evidentemente, a associação sincrética que existe no candomblé hoje, entre a primeira esposa de Xangô e a padroeira católica dos bombeiros e eletricistas, já era corrente na segunda metade do século XIX. ${ }^{44}$

Em uma sociedade que sistematicamente reprimia práticas religiosas africanas, essas referências ousadas ao panteão afrobrasileiro por um personagem conhecido certamente chamavam atenção. Na Bahia, a relação da sua família com Marcelina da Silva também não podia passar sem ser notado. Bamboxê Obitikô havia chegado à Bahia vindo de Lagos pouco antes da publicação do texto, no Monitor, que invocava a proteção de Ogum. Ademais, a reivindicação de realeza já tinha se tornado público. Bamboxê era natural de Oyó e fazia parte da rede sociorreligiosa do pai de Candido. Não há dúvida de que soube que Candido afirmava fazer parte da casa real de Oyó."

\footnotetext{
${ }^{43}$ Seu registro de batismo o identifica meramente como "Candido, crioulo, filho natural de Maria de São José, forra". Como de praxe para filhos naturais, o nome do pai não aparece no registro. Em 1844, Maria de São José casou-se com Bemvindo da Fonseca Galvão, cujo testamento, escrito anos depois, estabelece que era pai "do alferes Candido da Fonseca Galvão" (ACMS. Freguesia da Sé. Batismos 1829-1840, fl. 155v:; Casamentos 18381879, fl. 43; APB. Setor Judicial. Inventário de Bemvindo da Fonseca Galvão (1877), 05/2134/2603/14, fls. 4-4v). Em um de seus primeiros trabalhos publicados enquanto ainda vivia na capital baiana, Candido se descreveu como "filho da cidade de São Salvador" (O Monitor, Bahia, 29 set. 1877).

${ }^{44}$ O Monitor, Bahia, p. 2, 13 dez. 1878; O País, p. 4, 23 out. 1885; O Carbonário, p. 4, 16 jul. 1886. A associação, na mitologia iorubá e afro-brasileira, de Xangô com relâmpagos é bem conhecida (Verger, 2003 [1981], p. 134-140 e 168-170; Parés, 2014; Silva, 1999, p. 168-170).
} 


\section{Realeza africana no Brasil}

Um número significativo das narrativas deixadas por africanos escravizados no mundo anglófono são de pessoas que foram de descendência real. Isso sugere que não era incomum que membros da realeza ou da nobreza acabassem vendidos para a escravidão nas Américas, o que não surpreende muito. Os reinos africanos explorados pelo comércio de escravos eram relativamente pequenos, e em cada Estado geralmente havia várias linhagens reais. Ademais, homens da nobreza tomavam numerosas esposas, o que resultava em grandes números de filhos. Tudo isso significa que a população real e/ou nobre era relativamente numerosa em relação à comum. As causas de escravização variavam entre capturas durante guerras, sequestros e disputas entre linhagens pelo trono ou por títulos de nobreza. No que diz respeito ao Brasil, Pierre Verger afirma de forma convincente que o panteão de voduns cultuados na Casa das Minas, em São Luís, Maranhão, indica uma ligação setecentista com a família real do Daomé. ${ }^{45} \mathrm{Na}$ Bahia, a tradição oral do terreiro do Alaketu reivindica que a fundadora fosse de uma linhagem real do reino de Ketu, o que é apoiado por evidências que mostram que uma filha do rei foi aprisionada pelos daomeanos no final do século XVIII. E depoimentos pelo filho de um chefe ijebu indicam que ele foi levado a Recife como escravo por volta de 1820. Ademais, no Rio de Janeiro imperial, Candido da Fonseca Galvão não foi o primeiro negro a reivindicar descendência real africana. Nos anos 1870, o liberto Miguel Manoel Pereira ganhou notoriedade por reivindicar o título de "Príncipe Natureza" (Silva, 1999, p. 17; Silva, 2000; Engel, 2001, p. 37; Castillo, 2011b; Santana, 2015).

Ainda assim, a ideia de que o pai de Candido da Fonseca Galvão fosse filho do alaafin Abiodun carece de apoio. Embora Bemvindo da Fonseca Galvão tenha nascido entre 1779 e 1787, quando Abiodun estava no trono de Oyó, ${ }^{46}$ as tradições orais citadas por historiadores do reino não sugerem que tivesse desaparecido algum príncipe do palácio nos tempos de Abiodun. Pelo contrário, o reinado desse monarca é lembrado como um dos períodos mais pacíficos da história do império. É mais plausível que um de seus filhos possa ter sido vendido para a escravidão após a morte do alaafin, por volta de 1789, porque daí surgiram as divisões internas que acabaram sugando o poder e a estabilidade do império (Johnson, 1966, p. 186-187; Law, 1977, p. 54-55 e 247-248). O grande número de pessoas apadrinhadas por Bemvindo da Fonseca Galvão sugere que ele fosse uma pessoa de importância na comunidade africana de Salvador, o que pode ter decorrido de algum prestígio que antecedeu sua escravização. Mas não há evidência alguma de que Bemvindo tenha feito a reivindicação de realeza que acabou se tornando a marca identitária da personalidade pública

\footnotetext{
${ }^{45}$ Ver, por exemplo, as narrativas de Job ben Solomon (Bluett, 1734), William Ansah Sessarakoo (1750) e Ukawsaw Gronniosaw (1772). Os estudos biográficos de Alford (1977) e Sparks (2009) demonstram que havia outros casos de membros de famílias reais que foram escravizados.

${ }^{46}$ De acordo com Robin Law, o alafin Abiodun reinou entre 1774 e 1789 (Law, 1977, p. 54-55 e 60). Em um documento de 1874, Candido afirmou que seu pai tinha 87 anos, o que aponta para seu nascimento em 1787; mas, em 1877, um anúncio de jornal sobre a morte de Bemvindo informou que ele morreu aos 98 anos, sugerindo que tivesse nascido em 1779 (Silva, 1999, p. 189-190; O Monitor, p. 1, Óbitos, 25 nov. 1877).
} 
de seu filho. Ao que parece, a única referência feita por Bemvindo a seus pais é em seu testamento, redigido em 1873, no qual afirmou:

Sou natural da Costa da África, de onde me transportaram, ainda de menor idade, como escravo para esta cidade, capital desta Província da Bahia, e [...] que depois que vim da terra do meu nascimento [...] nunca mais, até o presente, tive notícias do meu Pai e nem da minha Mãe, e por isso não sei se eles são vivos ou se já faleceram da vida presente. ${ }^{47}$

Embora Bemvindo não forneça informações sobre os nomes ou posição social de seus pais, seu depoimento sugere que ainda estivessem vivos quando foi levado como escravo. Mas, se fosse filho de Abiodun, certamente teria recebido as notícias da morte do rei posteriormente, por meio dos inúmeros outros oyós que chegaram à Bahia como escravos durante a primeira metade do século XIX. Nesse sentido, o desconhecimento de Bemvindo, em 1873, sobre o destino de seu pai parece contradizer a ideia de que fosse filho do alaafin Abiodun.

Podemos considerar significativo, portanto, que foi alguns meses depois da morte de Bemvindo, no final de 1877, que Candido começou a reivindicar descendência real. A questão gerou logo certo ceticismo, e havia quem dissesse, inclusive, que ele estava precisando de assistência médica. Surgiu uma proposta de recolher doações para "uma caixa cujo fim é uma consignação mensal para [seu] tratamento". Candido, entretanto, se recusou a voltar atrás. Em 20 de janeiro de 1878, publicou uma nota no jornal baiano $O$ Monitor, insistindo em ser tratado como "Sua Alteza o Sr. Alferes Candido da Fonseca Galvão, filho do finado príncipe Obá I — neto de Sua Majestade, o rei da África, Abiodun” e advertindo que de jeito nenhum deixaria "de ser príncipe d'África". 48

Embora os primeiros escritos de Candido tivessem focalizado problemas sociais e acontecimentos políticos, defender sua descendência real de seus críticos passou a consumi-lo. Foi no final de 1885 que ele teve a ideia de ser nomeado embaixador em Lagos, uma sugestão que virou piada na imprensa. Naquela altura, os escritos de Candido haviam se tornado cada vez mais incoerentes, um problema que se devia, ao que parece, à sua crescente tendência a exagerar na bebida. No final de 1879, quando ainda morava na Bahia, foi obrigado pela polícia a assinar um termo de bem-viver, e posteriormente, durante sua campanha para ser nomeado embaixador, foi preso no Rio diversas vezes por embriaguez. ${ }^{49}$ Ainda assim, não há dúvida de que o racismo também influenciava a forma zombeteira com a qual ele era tratado pela imprensa, fato que não passou despercebido por ele. ${ }^{50}$

\footnotetext{
${ }^{47}$ APB. Inventário de Bemvindo da Fonseca Galvão, 5/2134/2603/14, fl. 4; grifos nossos.

${ }^{48}$ O Monitor, p. 2, Ineditoriais, 20 jan. 1878; O Monitor, p. 2, 21 fev. 1878.

49 Ver, entre outros, O Monitor, Bahia, p. 2, 17 dez. 1879; Diário de Notícias, p. 3, Ao país, 13 nov. 1885; Diário de Notícias, p. 1, Notas suburbanas, 3 jan. 1886; Diário de Notícias, p. 2. Um príncipe na touca, 4 maio, 1886.

50 Ver, por exemplo, Diário de Notícias, p. 3, 4 mar. 1886.
} 
Candido se defendia por escrito, vigorosa e prolixamente, mas sobrava frustração, a qual atingiu outras áreas de sua vida. O conflito com a mina liberta Maria da Conceição, já mencionado, é um claro exemplo. O desentendimento chegou à imprensa em 1883 e estourou novamente em 1886, poucas semanas antes da chegada de Bamboxê ao Rio. Em 22 de março, o jornal O Carbonário, de que Candido era colaborador regular, publicou uma denúncia velada, assinada por "um amigo de d. Obá II", que acusava Maria da Conceição de prostituir sua filha. Poucos dias depois, ela foi à polícia e deu queixa, alegando que Candido da Fonseca Galvão tentara invadir sua casa com o objetivo de estuprar sua filha. Candido recorreu à imprensa, publicando uma série de matérias em que descartava a acusação como uma mera invenção de inimigos que queriam impedir sua nomeação como embaixador de Lagos. Atacou também o caráter da mãe, retratando-a de cafetina e feiticeira. A briga se arrastou por meses, recebendo bastante atenção na imprensa - sobretudo nos escritos do próprio Candido —, e ele foi preso duas vezes. ${ }^{51}$ Não há dúvida de que a maioria da população mina-nagô da corte sabia da querela, inclusive Bamboxê Obitikô, que chegou à cidade em abril, justamente quando a situação estava se desdobrando. Parece provável, inclusive, que Maria da Conceição tomasse a decisão de ser iniciada por ele no culto aos orixás com o intuito de se fortalecer espiritualmente para poder livrar-se das acusações do alferes Galvão.

\section{Não era incomum que membros da realeza ou da nobreza acabassem vendidos para a escravidão nas Américas}

Após a prisão de Bamboxê durante essa cerimônia de iniciação, ele permaneceu no Rio de Janeiro por mais seis meses. Não se sabe se sua permanência se devia a algum processo jurídico decorrente do acontecido ou se ele foi liberado depois de pagar a multa, retomando, clandestinamente, suas atividades como babalaô e babalorixá. De qualquer forma, quando finalmente foi para a Bahia, em 16 de janeiro de 1887, seu desembarque virou matéria do jornal Gazeta de Notícias, com a manchete "Príncipe africano":

A bordo do paquete Niger, partiu anteontem para a Bahia, de onde, depois de certa demora, seguirá para a África, um ilustre personagem, que, durante a sua estada aqui, guardou o maior segredo sobre a sua alta posição e origem. Referimo-nos ao príncipe Manuel Rodolpho, chefe da valente tribo dos Nagô, de Yobá [sic], na África.

\footnotetext{
${ }^{51}$ Cf. Protesto solene contra o rapto. O Carbonário, 26 mar. 1886; É verdade e consciência. O Carbonário, p. 4, 11 jun. 1886; O Carbonário, p. 4, 14 jun. 1886; Gazeta de Notícias, Rio de Janeiro, p. 1, Prisão de um príncipe, 28 jul. 1886. Passagem de Venus pelo disco Solar. O Carbonário, 22 mar. 1886, p. 4; O Príncipe Obá II. Diário de Notícias, 24 mar. 1886, p. 4; O Príncipe Obá, Gazeta de Notícias, Rio de Janeiro, 24 mar. 1886, p.1;
} 
As mulheres, de vestido de chita de cores vivas, trazendo a cabeça envolvida em enorme turbante, e um xale de lã cobrindo o decote da camisa; os homens trajavam severo casaco e calça preta, chapéu de palha. Toda esta gente despertou natural curiosidade das pessoas que estavam a bordo. Sabia-se que havia ali um príncipe. Qual era ele? Ninguém sabia responder. Afinal, quando o navio estava para partir, Sua Alteza veio até tombadilho despedir-se da sua gente, e pôde-se então reconhecer o Príncipe Rodolpho, que traz esculpidos no rosto os brasões da sua raça.

Sua Alteza foi chamado a Yobá para defender a sua tribo, que está em luta com outras tribos vizinhas. Sua Alteza foi acompanhado a bordo por um grande número de súditos seus, que lhe fizeram uma significativa manifestação. Logo que chegou a bordo, o príncipe recolheu-se no seu camarote, deixando os seus súbditos à sua espera no tombadilho do vapor. ${ }^{52}$

Ao se referir ao protagonista da matéria como príncipe Manoel Rodolpho, o jornalista aludia ao arquiduque Rodolfo, príncipe-herdeiro do Império Austríaco e assunto frequente de notícias. Ao identificá-lo como natural de "Yobá", a matéria também convidava o leitor a comparar a personagem com dom Obá II. Apesar de não divulgar o sobrenome, não há dúvida de que o "Príncipe Manoel Rodolpho" era Rodolfo Manoel Martins de Andrade. O príncipe Manoel Rodolpho evidentemente passou uma estada relativamente longa no Rio; Bamboxê ficou nove meses. O príncipe viajou para a Bahia no vapor Niger, que naquele mesmo dia levou Rodolfo Manoel Martins de Andrade. Segundo a matéria, Manoel Rodolfo pretendia passar um tempo na Bahia antes de seguir para a África; Rodolpho Manoel Martins de Andrade permaneceu em Salvador até outubro, quando embarcou para Lagos (Castillo, 2012, p. 102). Embora não mencionasse qualquer atividade religiosa, muito menos sua prisão no zungu seis meses antes, o jornalista demonstrou um grau de conhecimento sobre as atividades do "príncipe", o que leva a pensar que conhecia Bamboxê pessoalmente ou que tivesse sido acionado por pessoas próximas a ele.

Alguns elementos da matéria se assemelham ao estilo noticiado sobre Candido da Fonseca Galvão, como a ironia sutil sobre o peso de suas responsabilidades políticas e a devoção de seus súditos para com ele. Contudo, enquanto as matérias sobre o "Príncipe Obá" invariavelmente projetavam uma imagem de um trapalhão obcecado por bajulação, o "Príncipe Rodolpho" é representado como um homem de poucas palavras, que jamais procurara expor seu status. Aliás, a mera sugestão de que existisse outro príncipe iorubá no Brasil foi, decerto, uma maneira de alfinetar Galvão, cujos escritos sempre ressaltavam a singularidade de seu vínculo com a linhagem real de Oyó.

É preciso, portanto, reconhecer que a sugestão de que Bamboxê Obitikô fizesse parte da realeza iorubá pode ter sido um tropo literário, introduzido para fins de criar a comparação com dom Obá II. Seria precipitado tomar essa

${ }^{52}$ Gazeta de Notícias, Rio de Janeiro, p. 2, 18 jan. 1887; grifo do original. 
matéria como prova definitiva da reivindicação de descendência real sustentada pelos descendentes atuais de Bamboxê Obitikô em Lagos. Mas o certo é que essa descrição de sua partida da corte em 1887 sinaliza que Bamboxê Obitikô já tinha alcançado uma posição de renome e até de prestígio entre a população mina da cidade. Entre aqueles que foram assistir ao desembarque do navio, decerto havia muitos clientes, filhos de santo e outras pessoas ligadas ao povo de santo com quem ele teve contato durante sua estada no Rio de Janeiro.

\section{Uma terceira visita ao Rio}

Sete anos depois, durante sua próxima visita ao Brasil, Bamboxê retornou ao Rio. Mais uma vez, ele esteve ativamente envolvido no culto aos orixás. $\mathrm{Na}$ noite de 29 de maio de 1893, a policia atendeu a uma reclamação sobre uma "casa de dar fortuna" na rua General Camara, 305, esquina com Núncio, localizada a uma quadra do zungu onde Bamboxê foi preso em 1886. Ao chegar ao local, as autoridades encontraram Rodolfo Manoel Martins de Andrade, cinco outras pessoas e "diversos manipansos, ervas, patuás, e outras bugingangas", usadas como "remédios para as enfermidades e para dar fortuna". ${ }^{53}$ Cinco jornais publicaram reportagens sobre o incidente. Todos identificaram Rodolfo Manoel Martins de Andrade como o dono da casa e líder das atividades. ${ }^{54} \mathrm{Um}$ jornal, O Tempo, se referiu a um apelido, "Bambucho", que outro jornal, o Diário de Notícias, interpretou como "Bombaché". ${ }^{55}$ Apesar das pequenas discrepâncias, é evidente que ambas são corruptelas do nome iorubá do nosso personagem, deixando claro que era como Bamboxê, e não como Rodolfo Manoel Martins de Andrade, que seus clientes e filhos de santo o conheciam no Rio.

Segundo o Diário de Notícias, ele era um curandeiro que "iludia e extorquia o dinheiro dos incautos", enquanto para O Tempo era um "feiticeiro velho".56 A caracterização da faixa etária não foi à toa. A essa altura, Bamboxê Obitikô provavelmente tinha mais de 70 anos. Mas, naquela conjuntura social, ser chamado publicamente de feiticeiro e curandeiro foi algo muito sério. O novo Código Penal brasileiro, aprovado em 1890, criminalizava tanto o curandeirismo quanto a magia ou feitiçaria, enquadrados como crimes contra a saúde pública (Dantas, 1988, p. 165-172). A pena era uma multa de 100 a 500 mil réis ou a prisão de um a seis meses. ${ }^{57}$ Vários jornais citaram as "bugigangas" e

\footnotetext{
53 Diário de Notícias, p. 1, 30 maio 1893. Manipanso é um termo de origem bantu usado para descrever icones como esculturas e também divindades africanas (Possidonio, 2015, especialmente p. 122-123). Alguns meses antes desse incidente, objetos semelhantes foram encontrados no mesmo endereço durante uma investigação de casas de cômodo em um quarto pertencente a Eleutério Ferreira Brito (Diário de Notícias, p. 2, 8 fev. 1893). E, em 1883, 11 pessoas haviam sido presas lá pelo mesmo motivo (Gazeta de Notícias, Rio de Janeiro, p. 2, Casa de dar fortuna, 1o fev. 1883). Os nomes, entretanto, não coincidem com os das pessoas encontradas com Bamboxê.

${ }^{54}$ Diário de Notícias, p. 1, 30 maio 1893; O Tempo, p. 1, 30 maio 1893; Jornal do Brasil, p. 1, 30 maio 1893; Gazeta de Notícias, p. 1, 30 maio 1893; O País, p. 2, 30 maio 1893.

${ }_{55}$ Diário de Notícias, p. 1, 30 maio 1893; O Tempo, p. 1, 30 maio 1893.

${ }^{56}$ Diário de Notícias, p. 1, 30 maio 1893; O Tempo, p. 1, 30 maio 1893.

${ }^{57}$ Cf. no Capítulo III, artigos 157 e 158, do Decreto no 847, de 11 de outubro de 1890, a promulgação do Código Penal dos Estados Unidos do Brasil. Disponível em: <legis.senado.gov.br/legislacao/ListaPublicacoes. action?id=66049>. Acesso em: 12 nov. 2015.
} 
outras "coisas de feitiçaria" encontradas pela polícia. Na versão de O Tempo, havia vários animais: um cabrito, uma galinha e 18 tartarugas. Sem dúvida, estas últimas eram na verdade cágados, um dos animais oferecidos a Xangô durante rituais de iniciação (Johnson, 1966, p. 34). Esse é um detalhe importante, porque Xangô é o patrono do terreiro que, de acordo com a tradição oral, Bamboxê Obitikô ajudou a fundar no Rio de Janeiro (Augras e Santos, 2005). Não fica claro se esse incidente envolvia outras pessoas associadas àquele terreiro, mas de qualquer forma comprova que Bamboxê realizava rituais para Xangô naquela cidade e ainda trazia novas pessoas para o culto.

Ainda outro jornal, $O$ País, deu uma descrição detalhada das atividades que a polícia teria encontrado:

Lá encontrou duas mulheres ajoelhadas diante de um manipanso, cada uma com uma coroa de chifres na cabeça. Diante do bicharoco ardiam ramos de alecrim e de murta em tabuleiro de latão. Outra mulher de cabeça rapada [sic] e colar de bugigangas no pescoço descarnado dizia coisas a esmo, tirando cartas de um baralho preto. Nem viu a autoridade que se aproximava, e que, de perto, conseguiu ver-lhe o couro cabeludo pintado de cruzinhas vermelhas. Quando o delegado da $4^{\mathrm{a}}$ mandou lavar a cabeça, ela despertou do letargo, ocultou o baralho no seio e gritou, aporrinhada: "Sorte negra te persegue!" Num quarto estavam duas mulheres estendidas no chão, uma em cruz sobre a outra, ambas de mãos postas, olhos fechados, e cantando baixinho um coro monótono. De pé, junto delas, um negro alto e quase nu batia com um fêmur sujo numa caveira pintada de verde. ${ }^{58}$

O jornalista não menciona como soube dos detalhes da cena, mas presumivelmente foi pela polícia. Alguns parecem ser exageros introduzidos para dar um tom sinistro. O "bicharoco", por exemplo, era provavelmente o cabrito mencionado por O Tempo. Outros elementos, como o "jogo de baralho negro" e o "crânio e ossos", são do imaginário da magia europeia, provavelmente floreios acrescentados pelo jornalista de acordo com os estereótipos que enxergavam o culto aos orixás pela lente da bruxaria. Entretanto, algumas coisas são mais convincentes, como as folhas encontradas perto do "bicharoco". Nos rituais de candomblé, animais de quatro pés oferecidos como sacrifício são alimentados com plantas medicinais. $\mathrm{O}$ ato de se ajoelhar — ou, mais frequentemente, de se prostrar diante do altar é um gesto que sinaliza respeito. O significado de cabeças raspadas já foi mencionado em relação ao zungu de 1886. O "colar de bugingangas" usada pela noviça pode ter sido um kelê, colar usado por um período logo depois da iniciação. Novamente, a batida da polícia em 1893 interrompeu uma cerimônia de iniciação realizada por Bamboxê, evidentemente, para o culto de Xangô."

Além de Rodolfo Manoel Martins de Andrade, cinco outros participantes foram citados: Alexandrina Maria dos Reis, Sabina Theodora Torres, Antônia Francisca Torres, Manoel do Bomfim e Maria Júlia. ${ }^{59}$ Embora o sobrenome desta

58 O País, p. 1, 30 maio 1893.

59 O Tempo, p. 1, 30 maio 1893; Jornal do Brasil, p. 1, 30 maio 1893; Gazeta de Notícias, Rio de Janeiro, p. 1, 30 maio 1893; O País, p. 2, 30 maio 1893. 
última não fosse revelado, tratava-se, sem dúvida, da filha de Bamboxê. Ela já estava na cidade desde pelo menos o mês anterior, quando houve uma batida policial a um grupo bem maior de "feiticeiros" em uma casa na rua Souza Barros na freguesia semirrural do Engenho Velho. Entre as 18 pessoas presas estava Maria Júlia de Andrade. Tratava-se de outra cerimônia de iniciação: além dos "manipansos" e outros objetos rituais, a reportagem fazia referência a participantes com a cabeça raspada. A denúncia feita à polícia se referiu a um "padre negro", aparentemente o líder, mas quando as autoridades chegaram, ele não se encontrava mais. ${ }^{60}$ Contudo, uma vez que Maria Júlia de Andrade era uma dos participantes, é bem provável que o "padre" tenha sido o próprio Bamboxê.

\section{A associação sincrética que existe no candomblé hoje, entre a primeira esposa de Xangô e a padroeira católica dos bombeiros e eletricistas, já era corrente na segunda metade do século XIX}

Esses três incidentes mostram o envolvimento de Bamboxê Obitikô e de sua filha Maria Júlia em atividades religiosas no Rio de Janeiro nas últimas décadas do século XIX, confirmando, assim, as tradições orais cariocas sobre a importância da família no culto aos orixás em num período formativo. A maioria das pessoas envolvidas nessas cerimônias certamente morava no Rio, mas outras podem ter vindo da Bahia com o intuito de participar nos rituais. $\mathrm{O}$ Manoel do Bomfim que foi preso junto com Bamboxê na rua General Câmara, por exemplo, pode ter sido seu filho de santo de mesmo nome, mencionado anteriormente, que morava em Salvador. Ainda é possível que Bamboxê e sua filha levassem para o Rio membros de sua rede social em Lagos que se encontravam no Brasil para visitas.

\section{Considerações finais}

Depois de sua visita ao Rio em 1893, Bamboxê retornou novamente a Lagos, pois, no início de setembro de 1895, sua esposa Orisabukola deu à luz mais uma filha, seguida por outra, a caçula do casal, em junho de 1897 (Castillo, 2012, p. 78). Não consegui localizar o registro, mas não há dúvida de que ele ainda fez outra viagem ao Brasil: como já vimos, ele faleceu na Bahia. Ao que parece, sua morte aconteceu antes de 1905, porque, quando João do Rio fez a matéria já citada, para os trechos referentes a Bamboxê utilizou o tempo passado.

60 Jornal do Brasil, p. 1, 21 abr. 1893; Cidade do Rio de Janeiro, p. 1, 21 abr. 1893; O Tempo, p. 1, 21 abr. 1893, p. 1; 0 País, p. 1, 2 abr. 1983. 
Embora vivenciasse em carne própria a perseguição do culto aos orixás, sendo preso pelo menos duas vezes, Bamboxê Obitikô também alcançou o alvorecer de apelos para um fim desse quadro, levantados primeiro por Nina Rodrigues. Baseado em pesquisa etnográfica em diversos terreiros da Bahia, o trabalho de Nina mencionava o Ilê Axé Iyá Nassô Oká (usando o apelido "Engenho Velho"), mas não fez qualquer menção a Bamboxê (Rodrigues, 2006 [1900], p. 50 e 101). O babalaô somente entrara na etnografia afro-baiana quatro décadas depois da matéria de João do Rio, citado em uma lista dos "feiticeiros" mais temidos da Bahia no século XIX.

Na mesma lista, consta João Alabá, decerto a pessoa homônima que morava no Rio de Janeiro, caracterizada por João do Rio como grande feiticeiro. O nome Alabá é iorubá, o que indica que ele era nagô ou descendente de nagôs (Campos, 1943, p. 305; Rio, 2006, p. 83; Odudoye, 2001 [1972], p. 86). ${ }^{61}$ Não se sabe se João Alabá e Bamboxê se conheciam, mas é provável. Evidentemente, o babalaô fazia parte de uma extensa rede constituída por nagôs que viajavam entre Salvador e Rio de Janeiro. Tudo indica que o alferes Candido da Fonseca Galvão fosse vinculado, de alguma forma, a essa rede. Ademais, vários viajantes atlânticos já mencionados também faziam parte desse vaivém de libertos, como Eliseu do Bomfim, que voltou de Lagos junto com Bamboxê em 1878. Eliseu esteve no Rio pelo menos duas vezes. Quando chegou pela primeira vez, em maio de 1879, Bamboxê já estava desde o mês anterior. O babalaô voltou para a Bahia em junho, mas Eliseu ficou até outubro do ano seguinte. Eduardo Américo de Souza Gomes, casado com a filha de Bamboxê, Maria Júlia Martins de Andrade, passou um mês no Rio de Janeiro em 1881, enquanto sua esposa e sogro estavam em Lagos. Talvez fizesse a viagem ao Rio para vender produtos trazidos da África, aproveitando para entregar cartas ou encomendas enviadas pelo sogro. ${ }^{62}$ Embora ainda não tenham chegado à luz indícios concretos de Joaquim Vieira da Silva no Rio, diante das memórias orais de sua presença e das evidências concretas sobre as idas de outros conhecidos seus, é bastante plausível.

O legado de Bamboxê Obitikô no culto aos orixás no Rio de Janeiro continua até hoje. Os primeiros herdeiros foram Mãe Aninha, sua filha de santo, e Felisberto Sowzer, seu neto. Nas primeiras décadas do século XX, ambos foram líderes importantes no mundo do candomblé até suas mortes, em 1938 e 1940, respectivamente. Nas próximas gerações foram substituídos por Agripina de Souza (uma das primeiras filhas de santo de Aninha), Cantulina Pacheco (neta carnal de Joaquim Viera da Silva e também filha de santo de Aninha) e Regina

\footnotetext{
${ }^{61}$ João Alabá é lembrado nas tradições orais como devoto de Omolu e fundador de um dos primeiros terreiros nagôs, localizado na rua Barão de São Félix (Rocha, 2000, p. 31-33).

${ }^{6}$ APB. Livro de saída de passageiros, v. 53,1877-1881, vapor Tarqués, 25/5/1879, e vapor Gisonde, 6/11/1880; Livro de entrada de passageiros, v. 3, 1879-1883, vapor Douro, 27/10/1880 e 12/7/1881, e vapor Equateur. 18/11/1880; maço 5909, Registros de passaportes, fl. 23v. (Eliseu do Bonfim). Sobre africanos libertos da Bahia que faziam comércio no Rio de Janeiro, ver Sampaio (no prelo).
} 
Topázio Sowzer (filha carnal de Felisberto Sowzer), todas elas naturais da Bahia. Além dessas pessoas, da descendência carnal e espiritual de Bamboxê Obitikô, outros baianos envolvidos no candomblé também se estabeleceram na então capital federal nesse período (Rocha, 2000, p. 32-35; Conduru, 2010; Augras e Santos, 2005).

A multifacetada trajetória de Bamboxê Obitikô fornece um estudo de caso que esclarece diversos aspectos da experiência vivenciada por africanos no Brasil escravocrata, bem como a influência do quadro político da queda do Império de Oyó sobre o crescimento do culto a Xangô. Ao mesmo tempo, ao seguir seus passos entre Salvador, Recife, Lagos e Rio de Janeiro, percebe-se a existência de sofisticadas redes sociorreligiosas, tanto no movimento de retorno à África quanto no trânsito a outras capitais do império, especialmente o Rio de Janeiro. Sua atuação nesta cidade constitui um exemplo bastante concreto do papel de atores "baianos" no crescimento do culto aos orixás durante as últimas décadas do século XIX, um fenômeno bastante comentado na historiografia e na etnografia da religiosidade afro-brasileira, mas relativamente pouco documentado.

A pesquisa que deu origem a este artigo recebeu apoio de várias agências de financiamento: Fapesb (2006-2008), CNPq (20092010), Capes (2010-2012) e Fapesp (2013-2015). Estou grata aos descendentes de Bamboxê Obitikô, especialmente a Air José de Souza, Erelu Lola Ayorinde e a finada Irene Sowzer Santos (1920-2014), pelo diálogo e interesse no projeto, e a Maria Clementina Pereira Cunha e Sílvia Hunold Lara, pela troca de ideias. Agradeço também aos pareceristas anônimos da Revista Tempo as sugestões e a Willys Santos a assistência com a tradução e a troca de ideias. 


\section{Referências bibliográficas}

ALFORD, Terry. Prince among slaves. Nova York: Oxford University Press, 1977.

AUGRAS, Monique; SANTOS, João Batista dos. Uma casa de Xangô no Rio de Janeiro. In: MOURA, Carlos Eugênio Marcondes de (Org.). So màvo :o amanhã nunca termina: novos escritos sobre a religião dos voduns e orixás. São Paulo: Empório de Produção e Comunicação, 2005.

BENISTE, José. O jogo de búzios. Rio de Janeiro: Bertrand Brasil, 1999.

BLUETT, Thomas. Some memories of the life of Job, the son of the Solomon high priest of Boonda in Africa. Londres: Richard Ford, 1734. Disponível em: <www.books.google.com.br>. Acesso em: 18 dez. 2015.

BRAGA, Julio. Sistema divinatório Bamboxê. In: SOUZA, Vilson Caetano de; SOUSA, Air José de (Org.). Minha vida é orixá. São Paulo: Ifá, 2011.

CABRERA, Lydia. Anagó: vocabulario lucumí (el yoruba que se habla em Cuba). Miami: Universal, 2007 [1970].

CAMPOS, João da Silva. Ligeiras notas sobre a vida íntima, costumes e religião dos africanos na Bahia. Anais do Arquivo Público da Bahia, n. 29, p. 291-309, 1943.

CAMPOS, Zuleica. Memórias etnográficas do sítio de Pai Adão. Revista de Teologia e Ciências da Religião, v. 4, n. 4, p. 9-34, 2005.

CASTILLO, Lisa Earl. Entre memória, mito e história: viajantes transatlânticos da Casa Branca. In: REIS, João José; AZEVEDO, Elciene (Org.). Escravidão e suas sombras. Salvador: EDUFBA, 2012.

. Entre a oralidade e a escrita: a etnografia nos candomblés da Bahia. Salvador: EDUFBA, 2008.

. Vida e viagens de Bamboxê Obitikô. In: JESUS, Air José Souza de; SOUZA JR., Vilson Caetano de (Org.). Minha vida é orixá. São Paulo: Editora Ifá, 2011a. p. 55-86.

. O terreiro do Alaketu e seus fundadores: história e genealogia familiar, 1807-1867. AfroÁsia, n. 43, p. 213-259, 2011 b.

. Mapping the nineteenth-century Brazilian returnee movement: demographics, life stories and the question of slavery. Atlantic Studies: Global Currents, v. 13, n. 1, p. 25-52, 2016.

; PARÉS, Luis Nicolau. Marcelina da Silva e seu mundo: novos dados para uma historiografia do candomblé ketu. Afro-Ásia, n. 36, p. 111-151, 2007.

CONDURU, Roberto. Das casas às roças: comunidades de candomblé no Rio de Janeiro desde o fim do século XIX. Topoi, v. 11, n. 21, p. 178-203, 2010.

COSTA, Valéria Gomes. Trajetórias negras: os libertos da costa d'África no Recife (1846-1890). Tese (Doutorado), Universidade Federal da Bahia, Salvador, 2013.

CUNHA, Manuela Carneiro da. Negros, estrangeiros: os escravos brasileiros e sua volta à África. São Paulo: Corrupio, 2012.

CUNHA, Maria Clementina Pereira. Não tá sopa: sambas e sambistas no Rio de Janeiro, 18901930. Campinas: Unicamp. 2015.

DANTAS, Beatriz Gois. Vovô nagô e papai branco: usos e abusos da África no Brasil. Rio de Janeiro: Graal, 1988.

ELTIS, David. The diaspora of yoruba speakers, 1650-1865: dimensions and implications. In: FALOLA, Toyin; CHILDS, Matt D. (Org.). The yoruba diaspora in the atlantic world. Bloomington: Indiana University Press, 2004.

ENGEL, Magali Gouveia. Os delírios da razão: médicos, loucos e hospícios (Rio de Janeiro, 18301930). Rio de Janeiro: Fiocruz, 2001.

FALHEIROS, Elaine Santos. Luís e Antonio Xavier de Jesus: mobilidade social de africanos na Bahia oitocentista. Dissertação (Mestrado), Universidade Federal da Bahia, Salvador, 2013.

FARIAS, Juliana Barreto. Mercados minas: africanos ocidentais na praça do Mercado do Rio de Janeiro (1830-1890). Tese (Doutorado), Universidade de São Paulo, São Paulo, 2012.

; GOMES, Flávio dos Santos; SOARES, Carlos Eugênio Líbano. Cidades negras: africanos, crioulos e espaços urbanos no Brasil escravista do século XIX. São Paulo: Alameda, 2006. FLORENTINO, Manolo. Alforrias e etnicidade no Rio de Janeiro oitocentista: notas de pesquisa. Topoi, p. 9-40, set. 2002.

GRAHAM, Sandra. Ser mina no Rio de Janeiro do século XIX. Afro-Ásia, n. 45, p. 25-66, 2012. 
GRONNIOSAW, James Albert Ukawsaw. A narrative of the most remarkable particulars in the life of James Albert Ukawsaw Gronniosaw, an African prince, as related by himself. 1772. Disponível em: <https://books.google.com.br>. Acesso em: 18 dez. 2015.

GURAN, Milton. Da bricolagem da memória à construção da própria imagem étnica entre os agudás do Benim. Afro-Ásia, n. 28, p. 45-76, 2002.

JOHNSON, Samuel. The history of the yoruba. Lagos: CMS Bookshops, 1966.

KRAAY, Hendrik. Os companheiros de dom Obá: os zuavos baianos e outras companhias negras na Guerra do Paraguai. Afro-Ásia, n. 46 , p. 121-161, 2012.

LAW, Robin. The oyó empire, c. 1600-c. 1836. Oxford: Clarendon Press, 1977.

; LOVEJOY, Paul. The biography of Mahommah Gardo Baquaqua: his passage from slavery to freedom in Africa and America. Princeton: Markus Wiener, 2007.

; MANN, Kristin. West Africa in the atlantic community: the case of the slave coast. William and Mary Quarterly, v. 56, n. 2, p. 307-334, 1999.

LIMA, Vivaldo da Costa. O candomblé da Bahia na década de 1930. In: OLIVEIRA, Waldir Freitas de; LIMA, Vivaldo da Costa (Org.). Cartas de Edison Carneiro a Artur Ramos. Salvador: Corrupio, 1987.

LOVEJOY, Paul E. The yoruba factor in the trans-atlantic slave trade. In: FALOLA, Toyin; CHILDS, Matt D. (Org.). The yoruba diaspora in the atlantic world. Bloomington: Indiana University Press, 2004.

MATORY, J. Lorand. Black Atlantic religion: tradition, transnationalism and matriarchy in the Brazilian candomblé. Princeton: Princeton University Press, 2005.

MATTOSO, Kátia de Queiróz. Bahia, século XIX: uma província no império. São Paulo: Nova Fronteira, 1992.

MOURA, Roberto. Tia Ciata e a Pequena África no Rio de Janeiro. Rio de Janeiro: Secretaria Municipal de Cultura, 1995.

ODUDOYE, Modupe. Yoruba names: their structure and meaning. Ibadan: Sefur Books, 2001 [1972]. OLIVEIRA, Maria Inês Cortes de. Viver e morrer no meio dos seus: nações e comunidades africanas da Bahia do século XIX. Revista USP, n. 28, p. 174-193, 1996.

OMIDIRE, Félix Ayoh; AMOS, Alcione. O babalaô fala: a autobiografia de Martiniano Eliseu do Bomfim. Afro-Ásia, n. 46, p. 229-261, 2012.

PARÉS, Luis Nicolau. Xangô nas religiões afro-brasileiras: "aristocracia” e interações "sincréticas". Revista África(s), v. 1, n. 1, p. 149-183, 2014.

; CASTILLO, Lisa Earl. José Pedro Autran e o retorno de Xangô. Religião e Sociedade, v. 35, n. 1, p. 13-43, 2015.

POSSIDONIO, Eduardo. Entre ngangas e manipansos: a religiosidade centro-africana nas freguesias urbanas do Rio de Janeiro de fins do oitocentos (1870-1900). Dissertação (Mestrado), Universidade Salgado de Oliveira, Niterói, 2015.

RAMOS, Cleidiana. Terreiro em Salvador será reativado depois de 20 anos. A Tarde, p. 6, 30 jun. 2014.

REIS, João José. From slave to wealthy African freedman: the story of Manoel Joaquim Ricardo. In: LINDSAY, Lisa; SWEET, James (Org.). Biography and the Black Atlantic. Filadélfia: University of Pennsylvania Press, 2013.

. Domingos Sodré, um sacerdote africano: escravidão, liberdade e candomblé na Bahia do século XIX. São Paulo: Companhia das Letras, 2008.

. Rebelião escrava no Brasil: a história do levante dos malês em 1835 (Edição revista e ampliada). São Paulo: Companhia das Letras, 2003.

; GOMES, Flávio dos Santos; CARVALHO, Marcus Joaquim de. Oalufá Rufino: tráfico, escravidão e liberdade no Atlântico Negro (c. 1822-c. 1853). São Paulo: Companhia das Letras, 2010. ; MAMAGONIAN, Beatriz. Nago and mina: the yoruba diaspora in Brazil. In: FALOLA, Toyin; CHILDS, Matt D. (Org.). The yoruba diaspora in the Atlantic world. Bloomington: Indiana University Press, 2004.

RIO, João do. As religiões no Rio. Rio de Janeiro: José Olympio, 2006.

ROCHA, Agenor Miranda. Os candomblés antigos do Rio de Janeiro. Rio de Janeiro: Mauad, 2000. 
RODRIGUES, Raymundo Nina. O animismo fetichista dos negros baianos. Revista Brazileira, t. VI-VIII, 1896.

. O animismo fetichista dos negros baianos. Rio de. Janeiro: UFRJ/Biblioteca Nacional, 2006 [1900].

SAMPAIO, Gabriela dos Reis. Juca Rosa: um pai de santo na Corte imperial. Rio de Janeiro: Arquivo Nacional, 2009a.

. Africanos em trânsito entre Salvador e Rio de Janeiro nas últimas décadas do século XIX. In: SOUZA, Evergton; RAGGI, Giuseppina; CARDIM, Pedro (Org.). Salvador da Bahia: retratos de uma cidade atlântica (séculos XVII-XIX). Salvador: EDUFBA; Lisboa: Cham. No prelo. Coleção Atlântica.

. Conexões Rio-Bahia: identidades e dinâmica cultural entre trabalhadores, 1850-1888. Acervo, v. 22, n. 1, p. 67-84, 2009b.

SANTANA, Aderivaldo Ramos de. Destinos de Osifekunde. Revista de História, $1^{\circ}$ jul. 2015. Disponível em: <www.revistadehistoria.com.br/secao/retrato/destinos-de-osifekunde $>$. Acesso em: 15 dez. 2015.

SANTOS, Flávio Gonçalves dos. Economia e cultura do candomblé na Bahia: o comércio dos objetos litúrgicos afro-brasileiros, 1850-1937. Ilhéus: Uesc, 2013.

SANTOS, João Batista dos. 21 cartas e um telegrama de Mãe Aninha a suas filhas Agripina e Filinha, 1935-35. Afro-Ásia, n. 36, p. 265-310, 2007.

SESSARAKOO, William Ansah. The royal African: memoirs of the young prince of Annamaboe. Londres: Reeve, Woodfall \& Barnes, 1750. Disponível em: <http://books.google.com.br >. Acesso em: 18 dez. 2015.

SILVA, Alberto da Costa e. Portraits of African royalty in Brazil. In: LOVEJOY, Paul E. (Org.). Identity in the shadow of slavery. Nova York: Continuum, 2000.

SILVA, Eduardo. Dom Obá II d'África: o príncipe do povo. São Paulo: Companhia das Letras, 1997. SOARES, Luiz Carlos. O "povo de cam" na capital do Brasil: a escravidão urbana no Rio de Janeiro do século XIX. Rio de Janeiro: 7Letras, 2007.

SOUZA, Vilson Caetano de. Felisberto Sowzer, um babalaô. In: SOUZA, Vilson Caetano de; SOUSA, Air José de (Org.). Minha vida é orixá. São Paulo: Ifá, 2011.

SPARKS, Randy. The two princes of Calabar: an eighteenth-century Atlantic odyssey. Cambridge: Harvard University Press, 2009.

VERGER, Pierre. Orixás. Salvador: Corrupio, 2003 [1981].

. Os libertos: sete caminhos na liberdade de escravos da Bahia no século XIX. Salvador: Corrupio, 1992. 